\title{
COUMARINS FROM THE ROOTS OF FERULA NEVSKII
}

V. Yu. Bagirov and N. P. Kir'yalov

Khimiya Prirodnykh Soedinenii, Vol. 6, No. 4, p. 465, 1970

UDC $577.15 / 17: 589.289$

The neutral fraction $(10 \mathrm{~g})$ of the resin from the roots of Ferula nevskii Korov. (yield of resin 15\%) was chromatographed on $\mathrm{Al}_{2} \mathrm{O}_{3}(600 \mathrm{~g}$, activity grade III, with chloroform as the solvent). The following coumarins were isolated: I) $\mathrm{C}_{24} \mathrm{H}_{28} \mathrm{O}_{4}$ with $\mathrm{mp} 185-186^{\circ} \mathrm{C}$ (from ethanol), $\mathrm{M}^{+}$with $\mathrm{m} / \mathrm{e} 380$ (mass spectrometry); II) $\mathrm{C}_{24} \mathrm{H}_{32} \mathrm{O}_{5}$ with mp $176-177^{\circ} \mathrm{C}$ (from diethyl ether), $\mathrm{M}^{+}$with $\mathrm{m} / \mathrm{e} 400$ (mass spectrometry). Coumarin $\mathrm{I}$ corresponds to badrakemone [1] and coumarin II to samarcandin [2]. Identification of coumarins was based on the absence of a depression of the melting point of mixtures with the corresponding authentic materials and their IR spectra. The roots were collected by A. A. Meshcheryakov in the Turkmen SSR (Kugitang).

\section{REFERENCES}

1. N. P. Kir'yalov, KhPS [Chemistry of Natural Compounds], 3, 363, 1967.

2. N. P. Kir'yalov and S. D. Movchan, KhPS [Chemistry of Natural Compounds], 4, 73, 1968.

\section{April 1970}

Komarov Institute of Botany, AS AzerbSSR

Komarov Botanical Institute, AS USSR 